\title{
Curriculum development in American Studies: Interdisciplinarity, student progression, and the Swedish-American paradox
}

\author{
Adam Hjorthén \\ Uppsala university, Sweden
}

\begin{abstract}
The article explores challenges and possibilities of curriculum development in American Studies in Sweden, a discipline that does not yet exist as a national degree-awarding subject. The aim is to investigate how advanced level learning in American Studies can be designed in relation to student progression. The backdrop to this problem is "the Swedish-American paradox"-the fact the many Swedish students have substantial prior experiences and knowledges about the United States, yet where the opportunities for academic education about North America are rather limited. While American Studies is a common discipline at North American and European universities, it does not have a strong foothold in Sweden. The article discusses the disciplinary history and educational tradition within American Studies, focusing on its interdisciplinarity. It then discusses how interdisciplinarity have been brought into American Studies curricula internationally, and how this sits within the framework of the Swedish Higher Education Ordinance. The American Studies case is juxtaposed to similar fields through a review of area studies MA programs in Sweden. The article ends with an exploration of the ways in which interdisciplinarity can be adopted as a learning outcome in relation to the challenge of student progression in Sweden.
\end{abstract}

Keywords: interdisciplinarity, student progression, curriculum development, American Studies, Area studies

\section{INTRODUCTION}

Sweden has a long history of relations with the United States, grounded in seventeenth-century colonial contacts, nineteenth- and twentieth-century mass migration, political relations, and cultural interchanges (see overview in Blanck \& Hjorthén, 202I). Many Swedes today experience a close social and cultural affinity with the United States (e.g., Åsard, 2016). Yet, the higher education in American Studies - the field covering studies of U.S. history, politics, society, and culture-is in Sweden very limited. While American Studies has been an established research field in the United States and most European countries since the mid-twentieth century, it has never established a strong foothold at Swedish universities. The fact that the popular interest in the United States is substantial but that the academic study of North America is noticeably limited constitutes a Swedish-American paradox, the significance of which is amplified through international comparisons.

American Studies emerged as a research field in the United States after the Second World War. It grew out of a mid-twentieth century combination of historical and literary approaches

\footnotetext{
*Correspondence: adam.hjorthen@engelska.uu.se
} 
to American cultural and intellectual history, and was from its inception informed by the idea of American exceptionalism - the notion that the United States is inherently different from other nations, founded not on a common history, ethnicity, or language, but on ideas of freedom and democracy. Over time, the field widened to incorporate sociology and political science, and became strongly influenced by cultural studies and critical theory, especially relating to the study of race (e.g., Maddox, 1998; Wiegman \& Pease, 2002). These developments have, in different ways, served to critically counter exceptionalist narratives. Although shaped during the last decades by a turn to transnational and global perspectives, studies of the U.S.-Mexico borderlands, and a heightened attention to Indigenous and settler colonial history, the field remains overwhelmingly focused on the United States.

The number of American Studies programs at U.S. universities and colleges today are counted in the hundreds. With U.S. capital and culture pouring into Europe after the Second World War, the academic study of North America spread on the curricula of many European universities. This was partly an effect of direct American involvement, where the U.S. State Department financed American Studies programs and institutes in Europe (e.g. Blaustein, 20I8; Chenetier, 2006; Skard, 1958). American Studies currently has a considerable presence in for example Great Britain, Germany, and the Netherlands, but also in the other Nordic countries, including in Denmark and Finland. In some countries, such as in Switzerland and Sweden, the study of North America has mainly been centered on American literature and become institutionalized within departments of English. In an international—and even Nordic — perspective, the relative absence of American Studies at Swedish universities is in other words noteworthy.

Individual scholars in Sweden have since the early-twentieth century studied the United States, working in disciplines across the humanities and social sciences. The first attempts at consolidating the study of North America were taken in the 1960s. These developments were centered at Uppsala University, where a permanent professorship in American literature was instituted in 1968. There was also a major, concurrent research project on Swedish emigration to North America at the university's history department, but attempts at incorporating a professorship in American history were never realized. In 1985, the Swedish Institute for North American Studies (SINAS) was founded at Uppsala, which was - and still remains - the only center devoted to the broader study of North America in Sweden. The establishment of the Swedish Association for American Studies (SAAS) in 1997 served to connect scholars researching North America-related topics at Swedish universities, gathering people within mainly literature, history, media and film studies, and political science (Blanck, 20IO; Lundén, 1998). The fact that American Studies has not gained a stronger institutional foothold at Swedish universities relates to the aforementioned paradox, to the fact that SINAS was originally instituted as a research center and only gradually developed a study program, and to the generally weak position of Area Studies in Sweden, with notable exceptions being the Nordic Institute of Latin American Studies in Stockholm founded in I95I and the Institute for Russian and Eurasian Studies in Uppsala established in 2009. SINAS, though, is smaller than both of these centers. At the time of writing, SINAS has two permanent faculty positions in American Studies and offer undergraduate courses in U.S. history, politics, culture, and literature. It is currently not possible to take a BA, MA, or PhD degree in American Studies in Sweden.

This article has grown out of curriculum development at SINAS, especially relating to exploratory work on future MA-level courses, and the challenges that have arisen regarding how to envision learning outcomes in a field that does not yet exist as a national academic degreeawarding subject. The aim of the article is to specifically investigate how advanced level learning 
in American Studies in Sweden can be designed in relation to student progression. That is, how the students' previous education when admitted to a higher education course or program relates to what knowledges and skills that they will gain during their studies, and whether the ultimate learning outcomes will be similar or dissimilar depending on the incoming experiences and knowledges of each student. In essence, this concerns the question of what we expect students to learn by completing an American Studies course, and how that insight can be used to forward Swedish curriculum development within the field.

There are four reasons for why this inquiry is significant, the first three of which relates specifically to American Studies. First, there has so far not been any research on pedagogical and curriculum development in American Studies in Sweden. Second, and somewhat surprisingly, there have been few studies on higher learning within the international American Studies field in general. Third, an aspiration of the article is to find ways to specifically reconcile the Swedish-American paradox - the combination of a perceived socio-cultural closeness and academic distance to North America—with student progression. Student interest in taking courses in American Studies in Sweden has in recent years been increasing. Should learning within the field develop in the coming years, this will become a crucial challenge to consider within the particular context of Swedish higher education. Fourth, by juxtaposing the case of American Studies curriculum development to other area studies programs in Sweden, the article highlights themes about student progression that has a broader relevance.

The article begins by canvassing the main research and educational traditions of the international American Studies field, focusing on its interdisciplinarity. It then discusses how interdisciplinarity has been brought into American Studies curricula internationally, and how this sits within the framework of the Swedish Higher Education Ordinance. The American Studies case is also juxtaposed to similar fields through a review of area studies MA programs in Sweden. The article ends with an exploration of the ways in which interdisciplinarity can be adopted as a learning outcome in relation to the challenge of student progression in Sweden.

\section{AMERICAN STUDIES: AN INTERDISCIPLINARY DISCIPLINE}

In one of the field's foundational texts, "Can 'American Studies' Develop a Method?" from 1950, cultural and literary scholar Henry Nash Smith staked out the aim of investigating "American culture as a whole." According to Nash Smith, the best available solution was "to conceive of American Studies as a collaboration among men working within the boundaries imposed by conventional methods of inquiry" (Nash Smith, 1950, p. 208). This foundational rationale has persisted within American Studies, where it is common for research publications to be clearly grounded in, for example, literary, historical, or anthropological methodologies, yet where scholars do not shy away from transgressing disciplinary expectations on what concepts, theories, or sources to incorporate in a given study. While American Studies in many countries has developed into a discipline in its own right-with its own associations, conferences, journals, academic prizes, and designated tenured lectureships and professorships-it has since its inception been an inherently interdisciplinary (rather than multi- or transdisciplinary) research field.

Considering that American Studies is an internationally widespread degree-awarding subject, there have been remarkably few studies devoted to higher learning in American Studies. An exception is the 2016 special issue of American Quarterly—one of the leading academic journals of the field. As Sze (2016) points out in the issue's introduction, "the capaciousness of American studies is one of the strengths of the field" (Sze, 20I6, p. 34I). In recent decades, 
"activist scholarship" and "radical pedagogy" (Sze, 20I6, pp. 34I-2) have been prominent elements of American Studies research and teaching in the United States, grounded in critical theory. Through the dominance of cultural studies, which has been described as a liminal inquiry shaped by boundary-crossings (Forstorp, 2006), the American Studies field remains grounded in an eclectic use of concepts and methods drawn from discipline-specific contexts.

In Europe, learning has commonly built on the broad and interdisciplinary nature of American Studies, but the exact configuration of its elements has differed between national and local contexts. As an example, we can look at two popular MA programs in Germany and Denmark. The John F. Kennedy Institute for North American Studies at the Free University of Berlin (FU) is one of the largest centers of its kind in Europe. Partly because of its resourceswith seventeen senior faculty and over thirty lecturers and researchers (as of 202I) —students can choose to focus on two of six disciplines offered at the institute: political science, sociology, economy, history, literature, and culture. Depending on their elected specialization, students can "engineer a specialist professional profile" within cultural studies, the humanities, and social sciences. Alongside disciplinary courses, students are also trained in "Interdisciplinary Studies," focusing especially on "comparative methods and transfer research" (John F. Kennedy Institute [JFKI], 20I6). Within Scandinavia, the University of Southern Denmark in Odense (SDU) has since 2003 offered a popular MA program in American Studies. Being a substantial yet smaller institution than FU, with seven faculty (as of 202I), the students study two general disciplinary tracks, in "culture" (including literature), and "history and society" (Center for American Studies [CAS], 20I7).

In comparison to the FU and SDU programs, the two existing American Studies bachelor courses at SINAS, offered on the A- and B-level, follow a disciplinary structure with teaching components (of 7,5 ECTS) in U.S. history, politics, media, and literature. The exception is a thematic A-level component on race and ethnicity in the United States. A central learning outcome of the A-level course is to create an "enhanced [...] understanding of the complexity and diversity of U.S. society," and an outcome of the B-level course is for students to gain "a deeper knowledge of central features of the cultural and societal life of the United States" (English Department, AI, 202I; English Department, BI, 202I).

Internationally, the ways in which the research field of American Studies have been instituted in higher education curricula might consequently be best defined as an interdisciplinary discipline. The relations between disciplinarity and inter-, trans-, multi-, or cross-disciplinarity have been discussed extensively (e.g., Lattuca, 200I; Nissen, 2006; Mobjörk et al., 2020), their differences defined largely by the level of disciplinary integration and the extent to which the boundaries between disciplinary concepts, methods, and theories become blurred. This can be a challenge for scholars in their individual research, especially in a country such as Sweden where disciplinary training (in history, political science, literature, etc.) still dominate in doctoral programs. In terms of student education, though, it is vital that the challenges of interdisciplinarity are met. One way of doing so is through teacher collaboration. Morrison (20I5) has emphasized the importance of establishing a common language and common concepts in interdisciplinary education (p. 188-I89). He moreover argues that interdisciplinarity is not a form of knowledge in itself, but "a matter of professional collaboration and teamwork" that happens "when the capacity of a single person is exceeded." Morrison thus defines interdisciplinarity as "a domain-general set of basic skills for collaborative work across differentiated individual expertises" (Morrison, 2015, pp. 198-199, 207). While interdisciplinarity for the individual American Studies scholar can be a fundamental analytical mindset and methodological approach, it is in terms of student 
learning reasonable to think about it in terms of teacher collaboration. This is especially important in small fields and departments.

\section{LEARNING IN AMERICAN STUDIES AND AREA STUDIES: THE CHALLENGE OF STUDENT PROGRESSION}

Writing about interdisciplinarity in American Studies, Hill (2016) argues that this in itself can be considered as a learning outcome. It is centered on teaching students to "combine diverse methods to study American cultural products and practices" (Hill, 20I6, p. 36I). Discussing her own work with an MA program introductory methods course, Hill also addresses the issue of progression and the benefit of helping students make use of their previous disciplinary studies. She notes that framing interdisciplinarity as a learning outcome within such a course necessitates treating students "as disciplinary experts in a cross-disciplinary conversation in the classroom" (Hill, 2016, p. 363).

Exactly what constitutes "progression" has been a topic of scholarly inquiry. It has been pointed out that it often is used vaguely both in policy documents and academic research. It can refer either to student learning development, or to the sequential development of an educational course component or program which, ultimately, concerns the quality of education (Säfström, 20I7). For the purposes of this article, I will henceforth focus on the progression of student learning. Although a form of progression that lacks a clear definition, it has an imprecise relation to the theoretical discussion about "learning" (Säfström, 2017, p. 57), and is associated with an assumption that knowledge incrementally becomes more "sophisticated" (Sikorski \& Hammer, 20IO), it is relevant in this specific context to think about student progression in relation to knowledges gained through previous experiences and higher education studies.

Looking at some examples of American Studies programs in Europe, the idea that interdisciplinarity could be a learning outcome in its own right - whether or not articulated during the programs inception-is in different ways represented in the MA programs at FU and SDU. One learning outcome at SDU is to "be able to work across more than one discipline" (CAS, 20I7), while FU states that a student will develop "an interdisciplinary understanding of [North American] regions and possess in-depth and extensive specialist knowledge" (JFKI, 20I6). At FU, for example, students take the equivalent of ${ }_{25}$ ECTS in interdisciplinary studies. This consists of a thematic lecture series taught by faculty from the institute's six disciplines, and two interdisciplinary courses, such as the course "Imagery and Race" on the construction of racial identities through visual media (JFKI, 2020). In these examples from FU and SDU, interdisciplinarity is framed in relation to knowledge-based learning outcomes. Considered as a form of disciplinary integration (Newell, 2013), these students are trained in combining different knowledges, methods, inquiries, and perspectives (Boix Mansilla \& Dawes Duraising, 2007; Newell \& Green, 1982) directed at gaining a better and more complex understanding of the United States.

The role of interdisciplinarity has also been considered within the relatively few area studies MA programs offered at universities in Sweden. A survey of the MA programs categorized as area studies (länderstudier) at Studera.nu, the website and national course catalog maintained by the Swedish Council for Higher Education, is provided in Table I. The survey was made in September 202I and has not included programs dealing with non-specific geographical regions or countries, including programs in migration, ethnicity, or genocide studies. It also does not include programs within specific disciplines that offer a regional or national focus (such as the MA program in "Commercial and Business Law with focus on Europe" at Linköping University), or programs centering on language (such as the MA program in German Studies, 
offered at the Faculty of Languages at Uppsala University). The programs covered by the survey should thus be comparable to the American Studies field, in their regional focus and in their potential for broad and interdisciplinary perspectives.

Table I. Master of Arts programs in area studies offered at Swedish Universities, as of September 202I. The right-hand columns list if (A) Interdisciplinarity is mentioned in the aim or content description of the study plan; (B) Interdisciplinarity is mentioned in the program's learning outcomes; (C) A bachelor's degree in humanities and social sciences is specified as the basic entry requirement to the program

\begin{tabular}{|c|c|c|c|c|}
\hline Program Name & University & A & B & $\mathrm{C}$ \\
\hline The Master of Arts Programme in European Studies & Lund University & $\mathrm{X}$ & $\mathrm{X}$ & $\mathrm{X}$ \\
\hline Masters Programme in Asian Studies & Lund University & $\mathrm{X}$ & $\mathrm{X}$ & $\mathrm{X}$ \\
\hline Master's Programme in Russian and Eurasian Studies & Uppsala University & $\mathrm{X}$ & $\mathrm{X}$ & $\mathrm{X}$ \\
\hline Master Programme in Middle Eastern Studies & Lund University & $\mathrm{X}$ & & $\mathrm{X}$ \\
\hline Master's Programme in European Studies (four alternative focuses offered) & Göteborg University & $\mathrm{X}$ & & $\mathrm{X}$ \\
\hline Master Programme in Latin American Studies & Stockholm University & $\mathrm{X}$ & & $\mathrm{X}$ \\
\hline Master's Programme in East and Central European Studies & Lund University & & $\mathrm{X}$ & \\
\hline Master's Programme in Asian Studies & Stockholm University & $\mathrm{X}$ & & \\
\hline Master's Programme in Euroculture & Uppsala University & & & $\mathrm{X}$ \\
\hline Master's Programme in Middle Eastern Studies & Stockholm University & $\mathrm{X}$ & & \\
\hline Master's Programme in Scandinavian Studies & Uppsala University & & & \\
\hline
\end{tabular}

As defined by the selection criteria, there are currently eleven area studies MA programs offered in Sweden, studying Europe, Asia, Latin America, the Middle East, Russia, and Scandinavia. Eight of these programs are explicitly presented in their respective course descriptions as being "interdisciplinary" or "multidisciplinary." However, only four programs include variants of interdisciplinarity as a learning outcome: interdisciplinarity (tvärvetenskap) is used at the European Studies and Asian Studies programs in Lund, and multidisciplinarity (mångvetenskap and flervetenskap) is included in Russian and Eurasian Studies in Uppsala and Eastern and Central European Studies at Lund (the latter program, though, does not explicitly refer to multidisciplinarity in the program description). These four programs list inter- or multidisciplinarity as a knowledge-based learning outcome. The notable exception is Russian and Eurasian Studies in Uppsala, where multidisciplinarity is also included as a skill-based learning outcome.

As in the example of the Russian and Eurasian Studies program, it is instructive to consider interdisciplinarity in relation to learning skills and abilities. Discussing the case of area studies, MacPherson (2015, p. 40) notes that students' "choices of disciplinary and interdisciplinary majors shape their ways of thinking and constructing knowledge." Based on her experience working with an Asian Studies program at a liberal arts college in Minnesota, MacPherson describes how they sought to address the problem of heterogenous student progression by introducing an entry-level course on "Interdisciplinary Approaches to Asia." The course gave an introduction to the "disciplines and interdisciplines" of the program (addressing for example questions of methodology and epistemology), provided an overview of "library-based research," and offered students "a view of Asian Studies beyond the college" (MacPherson, 2015, p. 4I).

The relation between knowledges and skills as learning outcomes is inscribed in the national System of Qualification in Sweden, governed by the Swedish Higher Education Ordinance (The 


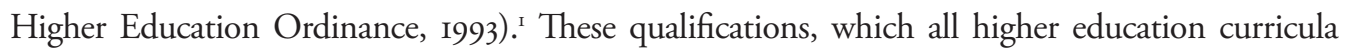
must legally follow, involve three learning outcomes on the MA level: (i) knowledge and understanding, relating to empirical and epistemological learning in the subject of study; (ii) competence and skills, encompassing generalist abilities such as critical and systematical analysis, the ability to "undertake advanced tasks within predetermined time limits," and to clearly report on knowledge and arguments in speech and writing; and (iii) judgement and approach, which includes assessment skills and ethical aspects on research. The importance of emphasizing generalist skills have in many countries increased in recent years, at least partly as a consequence of an intensified discussion about "employability" and the prospect of measuring educational success in terms of the rate of postgraduate employment (e.g., Studenternas anställningsbarhet, 2009). The relation between specialist knowledge and generalist skills, in turn, connects back to the problem of student progression.

From a practical standpoint, education on the MA level in American Studies in Sweden would necessitate a broad degree requirement for admission. The reason is, again, that unlike many other European countries-including the German and Danish programs discussed above-it is not possible to obtain a BA degree in American Studies in Sweden. Ideally, the admission requirement would therefore need to be a BA degree in any discipline within the humanities or social sciences. This would be a similar requirement to that used for the majority of the other Swedish MA programs in areas studies (e.g., Institute for Russian and Eurasian Studies [IRES], 2020). Three of the four area studies programs in Sweden that include interdisciplinarity as a learning outcome have a broad academic entry requirement of a bachelor's degree in the humanities or social sciences (see Table I). Students that enter a course or a program in American Studies on the MA level would thus have very different prior learning experiences, and the level of knowledge about North America specifically would vary greatly. If the degree that students would be awarded when finishing a future MA program is a degree in American Studies, this means that students who progresses into and out of the program will gain somewhat different empirical and epistemological knowledges depending on their previous studies and disciplinary specialty (which, in turn, would be influenced by the theme, theory, and methodology of their MA thesis). For such a program to fulfill the official requirements of the System of Qualification, students would need to gain the same generalist skills and abilities when progressing through the program. One way of doing so, I would argue, is to adapt the international culture of interdisciplinary American Studies to a Swedish context.

INTERDISCIPLINARITY: BENEFITTING FROM THE SWEDISH-AMERICAN PARADOX Considering interdisciplinarity as a learning outcome in its own right is productive both from a perspective of student progression in relation to official qualification systems, but also in thinking about preparing students for future careers and the job market. It would, moreover, be particularly conducive for studying American Studies from a vantage point outside the United States. This way of thinking about curriculum development should be relevant also for other area studies disciplines, that likewise are relatively new to the Swedish higher education system and that are characterized by some form of interdisciplinarity (i.e., at least eight of the eleven area studies programs surveyed in Table I). Interdisciplinarity as a learning outcome would combine several requirements in the Swedish system of qualification. It would fulfill the knowledge-based requirement to "demonstrate [...] broad knowledge of the field and a considerable degree of specialized knowledge in

1 The provisions discussed here concerns the qualifications for a degree of a two-year Master of Arts, as outlined in Annex 2, "Degree of Master (120 credits)," of the Higher Education Ordinance (1993:100). 
certain areas," as well as skill-based requirement to "demonstrate the ability to critically and systematically integrate knowledge and analyze, assess and deal with complex phenomena, issues and situations even with limited information" (The Higher Education Ordinance, 1993). Indeed, the latter requirement is included (often verbatim) as a skill-based learning outcome in many of the area studies program surveyed in this article. A noteworthy example of a program that emphasizes "multidisciplinary" as both a knowledge- and skill-based learning outcome is the MA program in Russian and Eurasian Studies at Uppsala University (IRES, 2020).

Building on the generalist skill qualification requirement, interdisciplinarity has the potential to train students in areas valuable on the job market. Newell and Green (1982) have argued that interdisciplinarity develop students' higher-order cognitive skills, as defined in Bloom's taxonomy, including "deductive reasoning," "reasoning by analogy," and, most importantly, "synthetic thinking" (Newell \& Green, I982, p. 29), grounded in the ability to approach a problem from multiple perspectives. Other abilities include training students to be "more sensitive to ethical issues," to gain an "ability to synthesize or integrate," to "enlarge perspectives or horizons," to stimulate "more creative, original, or unconventional thinking," to foster "more humility or listening skills," to instill a "sensitivity to bias", and to keep students more motivated (Newell, 1998). According to Lattuca, Voight, and Fath (2004), interdisciplinarity can train students to "forge connections to students' prior knowledge and experience," assist in "developing complex understanding," promote "sophisticated views of knowledge and learning," "influence thinking skills," train the capacity "to recognize, evaluate, and use differing (multiple) perspectives," increase interest and motivation, and stimulate active learning strategies (p. 44).

One way to work with interdisciplinarity in a learning context would be by introducing students to key concepts within the field. Cohen and Wang (2016) point out that the interdisciplinarity of American Studies "opens up the widest horizons, where almost any material that touches on some aspect of the United States is fair game" for teaching in an introductory course. The fact that there "might not even be consensus on what exactly we are introducing students to- a mode of inquiry, a set of critical thinking and reading skills, a series of intersecting themes, or historical narratives," might seem like a problem (Cohen \& Wang, 20I6, p. 347). In relation to the discussion of Hill (2016), though, it can also be framed as a strength.

Grounded in the strategy of Hill (2016), students would then be able to approach the concepts from different disciplinary perspectives. Examples of concepts that American Studies scholars commonly describe as central to understanding North American history, society, and culture include race, ethnicity, citizenship, empire, and settler colonialism (Cohen \& Wang, 2016; Owens \& Boggs, 2016). These are important concepts for creating an understanding of past and present scholarship within the field, and would clearly be central to MA courses offered also in Sweden. Indeed, the course "Race and Ethnicity in the United States," which is part of the A-level at Uppsala University, is such an example. As a means of learning the strengths and limitations of interdisciplinarity, such concepts could potentially be activated as focal points in learning centered on developing a complex understanding of North America.

A concrete example of how interdisciplinarity could inform curriculum development concerns the structure of the MA thesis. While the thesis should be completed within the interdisciplinary subject of American Studies, it is important to be mindful of the structural limitations of interdisciplinarity as some students may wish to progress to the doctoral level, where disciplinary degrees tend to be more easily evaluated and clearly defined academic identities valued (see for example the evaluation of thematic interdisciplinary education at Linköping University: Swedish National Agency for Higher Education, 2006, p. 25-26). The thesis thus needs to 


\section{Adam Hjorthén}

balance a set of different forms of interdisciplinarity as discussed by Lattuca (200I), seeking some level of disciplinary integration (of knowledge, concepts, methods, and theories), and teacher collaboration in planning, examination, and evaluation (p. II-I4). This could, for example, be done by creating an MA thesis course in American Studies, with an accompanying theory- and methods-course focusing on interdisciplinarity in the field of American Studies. To strengthen the disciplinary foundation of each thesis, students could then be assigned an advisor from a set of core disciplines — such as history, literature, political science, and media studies—with the student required to take an additional disciplinary methods course in the chosen specialization. Through this configuration, students would train their proficiency in applying disciplinary methodologies in interdisciplinary analysis, geared at gaining an awareness of how disciplinarity sits within, and can be productively related to, interdisciplinary studies.

An element of American Studies research and education beyond the United States, including in Sweden, concerns the local context and outside vantage point through which North America is studied. This is a key aspect of the field (though one that is handled differently depending on various, primarily historical, circumstances), is connected to the "transnational turn" in American Studies. Since the I990s, scholars have applied new perspectives, theories, and methods aimed at de-centering an exceptionalist U.S. narrative in favor of a greater attention to global contexts, transnational movements, borderlands, and Indigenous perspectives (e.g., Fisher Fishkin, 2005; Fluck et al., 20II; Tyrell, 2007). Not surprisingly, the transnational American Studies paradigm has informed teaching outside of the United States (Kim, 2016). Owens and Boggs (2016) have pointed out that while "much American studies pedagogy in the United States aims to defamiliarize nationalist myths, international students have not necessarily been subjectified in the same ways" (p. 383). That is certainly true, but it does not mean that non-U.S. students have not been subjectified at all. On the contrary, anecdotal evidence from teachers at SINAS, in combination with a small student survey ( $\mathrm{n}=\mathrm{I} 5$ students) conducted in the fall of 2020 within the entry-level course in American Studies at Uppsala University, shows that students generally take an intense interest in the United States and have considerable prior knowledge - and often experience — of the country. This is an illustration of the SwedishAmerican paradox discussed in the introduction, where students with significant but partial prior knowledge about North America seek a deeper and more complex understanding.

The question of prior learning and experience is addressed by McCentee (2007) in an article on the teaching of Hollywood film in an American Studies setting in Australia. In teaching students an academic approach to the study of film, McCentee presents a strategy where she "valorise students' pre-existing 'every day' knowledge, while encouraging them to extend, refine or interrogate their understanding" (p. 142). McCantee asserts that a casual, common sense, and everyday interest in the topic studied—such as "America" or "Hollywood film"—can be retained while also inculcating students in disciplinary thinking and knowledge. According to McCantee, "life-long students of American film don't cross thresholds so much as loiter in them" (McCantee, 2007, p. I43). It is clearly important to build on and challenge students' prior learning and individual experiences, but doing so entails a process geared to a heterogenous body of students whose knowledge and experiences are subjective, partial, and situated.

The prior knowledge and experiences of students in American Studies in Sweden is a further reason for the potential of interdisciplinarity as a learning outcome. While interdisciplinarity entails integrative learning that enables complex understanding of past and present phenomena in North American society, it needs to be set within a transnational approach. An example of a course that would be pivotal in an American Studies curriculum in Sweden concerns 
Swedish-American relations, broadly defined and approached. It should ideally be planned and taught by teachers from different disciplinary background, and be centered on literature that provides a variety of methods, themes, and perspectives in thinking about common problems relating to international exchanges and transnational entanglements. By making use of available tools for online teaching, such a course could easily be planned and taught together with practitioners (in business, government, media, NGOs, or the heritage sector) on both sides of the Atlantic. Incorporating the specific positionality of teachers and students, a transnational interdisciplinarity could in this way inform learning both in terms of epistemology and practice.

\section{CONCLUSION}

This article has explored challenges and possibilities of curriculum development in American Studies in Sweden, a discipline that does not yet exist as a national degree-awarding subject in higher education. A challenge of particular relevance has been the question of how to think about student progression; that is, the question of what we expect students who take American Studies courses to actually learn. The backdrop to this is the Swedish-American paradox-the fact the many students have substantial prior experiences and knowledges about the United States, yet where the academic study of North America in an international perspective is rather limited. This paradox, I suggest, can be framed as both the root cause and possible solution to the problem of student progression. The key for doing so is to make interdisciplinarity a learning outcome in itself. This has several potential benefits-for American Studies, but potentially also for other area studies disciplines. On a general level, geared towards postgraduate careers and life-long learning, it allows for proficiency in applying several methods and perspectives in analyzing a specific topic. Relating to American Studies in particular, it has the ability to draw on the engagement, prior knowledge, and experiences of students in learning complex understanding of North American society and culture, past and present. It could also be related to the question of employability, as some students may pursue employment in jobs and sectors where Swedish-American relations are significant, such as in business, government, or media. Seeking to foster career paths both within and outside academia, a transnational dimension could thus be paired with interdisciplinarity as a learning outcome in American Studies curricula.

\section{ACKNOWLEDGEMENT}

The author would like to thank his colleagues at SINAS and the Department of English at Uppsala University. A special thank you to Charlotta Magnusson and Lotten Gustafsson, who read an early draft of the article, to the two anonymous reviewers, as well as to Dag Blanck, Jørn Brøndal, and Lars Hagborg for helpful conversations about curriculum development in American Studies.

\section{DECLARATION OF INTEREST STATEMENT}

The author has been employed at the Swedish Institute for North American Studies (SINAS) at Uppsala University while writing this article.

\section{AUTHOR PRESENTATION}

Adam Hjorthén has a PhD in history and is Senior Lecturer in North American Studies at the Department of English, Uppsala University. He has previously taught history and American Studies at Stockholm University and the Free University of Berlin, and currently teaches courses in North American history, politics, and culture. His research focuses on U.S. cultural heritage and Swedish-American relations in the 2oth and 2ost centuries. 


\section{REFERENCES}

Åsard, E. (Ed.). (2016). Det blågula stjärnbaneret: USA:s närvaro och inflytande i Sverige. Carlssons.

Blanck, D. (2010, September 16-18). The early history of American Studies in Sweden [Conference presentation]. 6th Biannual Conference of the Swedish Association for American Studies (SAAS), Härnösand, Sweden.

Blanck, D. \& Hjorthén, A. (Eds.). (2021). Swedish-American borderlands: New histories of transatlantic relations. University of Minnesota Press.

Blaustein, G. (2018). Nightmare envy and other stories: American culture and European reconstruction. Oxford University Press.

Boix Mansilla, V. \& Dawes Duraising, E. (2007). Targeted assessment of students' interdisciplinary work: An empirically grounded framework proposed. Journal of Higher Education, 78(2), 215-237. https://doi.org/10.1080/00221546.2007.11780874

Center for American Studies, University of Southern Denmark. (2017, January 9). The curriculum for Master of Arts (MA) in American Studies. https://odin.sdu.dk/sitecore/index.php?a=sto\&id=30743 \&listid=905\&lang=en

Carmichael, P. (2010). Threshold concepts, disciplinary differences and cross-disciplinary discourse. Learning and Teaching in Higher Education, 7(2), 53-71.

Chenetier, M. (Ed.). (2006). Special issue on American Studies in European countries. European Journal of American Studies, 1(1). https://doi.org/10.4000/ejas.193

Cohen, M. M., \& Wang, G. (2016). Teaching the Introduction to American Studies Course: A dialogue. American Quarterly, 68(2), 347-354.

English Department, Swedish Institute for North American Studies. (2021, July 5). Syllabus for American Studies A1. https://www.engelska.uu.se/education/courses/course-syllabus/?kpid=44751 \&lasar $=21 \% 2 \mathrm{~F} 22 \&$ typ $=1$

English Department, Swedish Institute for North American Studies. (2021, July 5). Syllabus for American Studies B1. https://www.engelska.uu.se/education/courses/course-syllabus/?kpid=31589 \&lasar $=21 \% 2 \mathrm{~F} 22 \&$ typ $=1$

Fisher Fishkin, S. (2005). Crossroads of cultures: The transnational turn in American Studies; Presidential address to the American Studies Association. American Quarterly, 57(1), 17-57.

Fluck, W., Pease, D. E., Rowe, J. C. (Eds.). (2011). Re-framing the transnational turn in American Studies. Dartmouth College Press.

Forstorp, P.-A. (2006). Liminala metaforer och gränsarbete i den högre skolan: Kulturstudier och gränsernas mening. Utbildning \& Demokrati, 15(2), 41-61.

The Higher Education Ordinance. (1993). The Swedish Code of Statutes (HF 1993:100). https://www.uhr. se/en/start/laws-and-regulations/Laws-and-regulations/The-Higher-Education-Ordinance/

Hill, R. (2016). What is this thing called interdisciplinarity? Teaching interdisciplinary methods courses in American Studies. American Quarterly, 68(2), 361-365.

Holley, K. A. (2018). The role of threshold concepts in an interdisciplinary curriculum: A case study in neuroscience. Innovative Higher Education, 43, 17-30.

Huq, A., Nichols, M. D., \& Aryal, B. (2016). Building blocks: Threshold concepts and interdisciplinary structures of learning. In R. Land, J. H. F. Meyer \& M. T. Flanagan (Eds.), Threshold concepts in practice (pp. 135-154). Sense Publishers.

Institute for Russian and Eurasian Studies. (2020, June 4). Syllabus for Master's Programme in Russian and Eurasian Studies. Department of Informatics and Media, Uppsala University. https://www.uu.se/ utbildning/utbildningar/selma/utbplan/?pKod=SRE2M\&lasar=21\%2F22

John. F. Kennedy Institute for North American Studies, Free University of Berlin. (2016, November 2). Study and Examination Regulations for the Master's Degree Program in North American Studies at the John F. Kennedy Institute for North American Studies at Freie Universität Berlin. https://www.jfki. fu-berlin.de/en/academics/ma/2015_SPO_MA-Nordamerikastudien_EN.pdf 
John. F. Kennedy Institute for North American Studies (2021, March 2). "The Interdisciplinary Modules," M.A. North American Studies. Online Studienfachwahl-Assistenten, Free University of Berlin. https://www.osa.fu-berlin.de/north_american_studies_ma/en/curriculum/interdisciplinary_modules/ index.html

Kim, M.-J. (2016). The vexed location of teaching American Studies in South Korea. American Quarterly, 68(2), 371-378.

Lattuca, L. (2001). Creating interdisciplinarity: Interdisciplinary research and teaching among college and university faculty. Vanderbilt University Press.

Lattuca, L. R., Voight, L. J., \& Fath, K. Q. (2004). Does interdisciplinarity promote learning? Theoretical support and researchable questions. The Review of Higher Education, 28(1), 23-48.

Lundén, R. (1998). The uphill journey. In A. Shima \& H. Löfgren (Eds.), American Studies in the Nordic Countries. Swedish Institute for North American Studies.

Maddox, L. (Ed.). (1998.) Locating American Studies: The evaluation of a discipline. Johns Hopkins University Press.

McCantee, J. (2007). Inducing double vision, or does the 'threshold concept' account for how students learn about the Hollywood film? Australasian Journal of American Studies, 26(2), 136-152.

Mobjörk, M., Berglund, C., Granberg, M., \& Johansson, M. (2020). Sustainable development and cross-disciplinary research education: Challenges and opportunities for learning. Högre Utbildning, 10(1), 76-89.

Morrison, D. (2015). The underdetermination of interdisciplinarity: Theory and curriculum design in undergraduate higher education [Unpublished doctoral dissertation)]. University of Glasgow.

MacPherson, K. R. (2015). Decoding Area Studies and interdisciplinary majors: Building a framework for entry-level students. College Teaching, 63, 40-45. https://doi.org/10.1080/87567555.2014.977215

Nash Smith, H. (1950). Can 'American Studies' develop a method? American Quarterly, 9(2), 197-208.

Newell, W. H. (2013). The state of the field: Interdisciplinary theory. Issues in Interdisciplinary Studies, $31,22-43$.

Newell, W. H., \& Green, W. J. (1982). Defining and teaching interdisciplinary studies. Improving College and University Teaching, 30(1), 23-30.

Nissen, J. (2006). Tvärvetenskap och/eller gränsöverskridanden? Utbildning \& Demokrati, 15(2), 81-95.

O'Donnell, R. M. (2009). Threshold concepts and their relevance to economics. ATEC 2009, $14^{\text {th }}$ Annual Australasian Teaching Conference (pp. 190-200). Queensland University of Technology. https:// ro.uow.edu.au/commpapers/2137

Owens, C., \& Boggs, A. (2016). The global American Studies classroom: International students and critical pedagogy. American Quarterly, 68(2), 379-385.

Sikorski, T.-R., \& Hammer, D. (2010). A critique of how learning progressions research conceptualizes sophistication and progress. In K. Gomez, L. Lyons \& J. Radinsky (Eds.), ICLS'10 Proceedings of the 9th International Conference of the Learning Sciences. International Society of the Learning Sciences.

Säfström, A. I. (2017). Progression i högre utbildning. Högre Utbildning, 7(1), 56-75.

Skard, S. (1958). American Studies in Europe (2 vols). University of Pennsylvania Press.

Studenternas anställningsbarhet: Regeringens och högskolans insatser. (2009, December 14). Riksrevisionen (RIR 2009:28). https://www.riksrevisionen.se/download/18.78ae827d1605526e94b2e28a/ 1518435473482/RiR_2009_28.pdf

Swedish National Agency for Higher Education. (2006). Utvärdering av tematiska magister- och forskarutbildningar vid Linköpings universitet (Rapport 2006:43 R). https://www.uka.se/download/18.12f 25798156a345894e28bc/1487841896867/0643R.pdf

Sze, J. (2016). Introduction: Engaging contradictions: Teaching and pedagogy in American Studies. American Quarterly, 68(2), 341-345.

Tyrell, I. R. (2007). Transnational nation: United States history in global perspective since 1789. Palgrave Macmillan.

Wiegman, R., \& Pease, D. E. (Eds.). (2002). The futures of American Studies. Duke University Press. 